
КОНЦЕПЦІЯ ПІДГОТОВКИ МАЙБУТНІХ ФАХІВЦІВ ТРАНСПОРТНОЇ ГАЛУЗІ
ДО ПРОФЕСІЙНОЇ КОМУНІКАТИВНОЇ ВЗАЄМОДІЇ

\title{
THE CONCEPT OF TRAINING FUTURE TRANSPORT PROFESSIONALS FOR PROFESSIONAL COMMUNICATION
}

\begin{abstract}
У статті розроблено концепцію підготовки майбутніх фрахівців транспортної галузі до профресійної комунікативної взаємодії. Визначено поняття «концепція підготовки майбутніх фрахівців транспортної галузі до профресійної комунікативної взаємодіїз - це сукупність авторських ідей стосовно сутності педагогічного процесу, спрямованого на формування готовності майбутніх фрахівиів транспортної галузі до профресійної комунікативної взаємодії, що ірунтується на теоретико-методологічних положеннях, принципах і підходах. Підсумовано, що у вітчизняній системі підготовки майбутніх орахівців транспортної галузі існують суперечності між постійним підвищенням міжнародних мовних вимог і стандартів до майбутніх фрахівців транспортної галузі та їх реальною готовністю до професійної комунікативної взаємодії; потениіалом інноваційних технологій навчання й підходами до організації комунікативної підготовки майбутніх фрахівців транспортної галузі. Концепиія підготовки майбутніх орахівців транспортноі галузі до просресійної комунікативної взаємодії складається з трьох концептів: методологічного, теоретичного й практичного, які перебувають у взаємозв'язку та створюють підгрунтя для ії практичного впровадження у процес навчання через розроблення педагогічної системи підготовки майбутніх фахівців транспортної галузі до професійноі комунікативної взаємодії. Методологічний концепт призначений для з'ясування методологічних підходів і принципів авторської концепції; теоретичний концепт слугує для з'ясування сутності ключових понять, змісту та структури підготовки майбутніх фрахівців транспортної галузі до профресійноі комунікативної взаємодії; для виокремлення критеріїв, показників і рівнів готовності; для обгрунтування педагогічних умов; практичний кончепт потрібен для впровадження педагогічної системи підготовки майбутніх фахівців транспортної галузі до професійної комунікативної взаємодії.
\end{abstract}

Ключові слова: концепція підготовки, майбутні фрахівиі транспортної галузі, просресійна комунікативна взаємодія.

The article deals with the concept of training future transport professionals for professional communicative interaction. It was defined "the concept of training future transport professionals for professional communicative interaction", that is a set of author's ideas about the essence of the pedagogical process aimed at forming the readiness of future transport professionals for professional communication, based on theoretical and methodological provisions, principles and approaches. It is concluded that there are some contradictions in the domestic system of future transport professionals' training, namely: between the constant increase of international language requirements and standards for future transport professionals and their readiness for professional communication; between the potential of innovative learning technologies and approaches to the organization of communicative training of future specialists in the transport industry. The concept of training future transport professionals for professional communication consists of three concepts: methodological, theoretical and practical, which are interrelated and create a basis for its practical implementation in the studying process through the development of a pedagogical system for training future transport professionals for professional communicative interaction. The methodological concept is purposed to clarify the methodological approaches and principles of the author's concept; the theoretical concept serves to clarify the essence of key concepts, content and structure of training future transport professionals for professional communicative interaction; to identify criteria, indicators and levels of readiness; to substantiate pedagogical conditions; a practical concept is needed to implement a pedagogical system of training future transport professionals for professional communicative interaction.

Key words: training concept, future transport specialists, professional communicative interaction.
Постановка проблеми в загальному вигляді. Підвищення рівня профресійної підготовки майбутніх фрахівців транспортної галузі - одна з актуальних проблем, з огляду на постійне зростання транспортних перевезень, а також підвищення міжнародних стандартів та вимог до якості навчання. Незважаючи на затребуваність та професіоналізм фрахівців у цій галузі, на офріційному сайті Міністерства інфраструктури України відображено відомості, які свідчать, що зростає статистика аварій і катастрофр різних видів транспорту через порушення правил профресійної комунікації [1]. Це доводить і необхідність удосконалення професійної мовної підготовки майбутніх фрахівців транспортної галузі та фрормування їхньої готовності до про- фресійної комунікативної взаємодії. На такому тлі постає потреба у стратегічному підході до розроблення концептуальних засад педагогічної системи підготовки майбутніх фрахівців транспортної галузі до профресійної комунікативної взаємодії.

Аналіз останніх досліджень і публікацій. Базисним поняттям аналізу основних концептів підготовки майбутніх фрахівців транспортної галузі до професійної комунікативної взаємодії є поняття «концепція», що по-різному потрактовано в теорії тапрактиці педагогіки. У загальному розумінні «концепція» - це система доказів певного положення, система поглядів на те чи на те явище; тлумачення явищ [2, с. 571]. У словнику 3 педагогіки «концепція» охарактеризована як «система поглядів, 
певний спосіб розуміння, трактування явищ, процесів, погляд на сукупність явищ, керівна ідея для їх систематичного висвітлення, ключовий задум у структурі теорії» [3, с. 144].

Згідно з Є. Яковлевим, педагогічна концепція це «складна, цілеспрямована, динамічна система фундаментальних знань про педагогічний френомен, які повно і всебічно розкривають його сутність, зміст, особливості, а також технологію оперування ним в умовах сучасної освіти» [4, с. 196].

У розумінні Н. Волкової на результативність навчання впливають організація цього процесу, структура, зміст, фрорми, методи. Цим зумовлене існування різних концепцій навчання, які, на думку науковця, є «системою поглядів на процес навчання». Свідоме орієнтування на психологічну й дидактичну концепції детермінує вибір виду навчання або їх обґрунтоване поєднання [5, с. 293].

П. Гальперін висловив ідею про розроблення «концепції поетапного формування розумових дій», що ґрунтована на утворенні складних різнопланових змін, пов'язаних із орормуванням у людини нових дій, образів і понять. Науковець виокремлює шість етапів, у процесі яких відбуваються ці зміни: перший етап - формування мотиваційної основи дії, упродовж цього періоду в суб'єкта фрормується ставлення до цілей, завдань і змісту матеріалу навчання; другий етап - складання схеми орієнтовної основи дій, коли виокремлюють системи орієнтирів, які потрібно брати до уваги для виконання дії; третій етап - формування дій у матеріальній фрормі, суб'єкт виконує потрібні дії, керуючись схемою орієнтовної основи дій; четвертий етап - систематичне правильне виконання й багаторазове повторення дії, унаслідок чого зникає потреба у використанні орієнтовної схеми; ії зміст відображений у мовленні, що слугує опорою для дії; п'ятий етап - поступове зникнення звукової частини дії; шостий етап - мовленнєвий процес переходить у змістове наповнення дії [3, с. 145].

На підставі теоретичного й науково-методологічного узагальнення актуальних проблем фрормування підготовки майбутніх фрахівців транспортної галузі до професійної комунікативної взаємодії у ЗВО підсумовано, що у вітчизняній системі підготовки майбутніх фрахівців транспортної галузі існують певні недоліки й суперечності між: постійним підвищенням міжнародних мовних вимог і стандартів до майбутніх фрахівців транспортної галузі та їх реальною готовністю до професійної комунікативної взаємодії; потенціалом інноваційних технологій навчання й консервативними підходами до організації та змісту комунікативної підготовки майбутніх фрахівців транспортної галузі; сучасними вимогами до якості професійної підготовки фахівців транспортної галузі у ЗВО та реальною профресійно-педагогічною й методичною готовністю викладачів для реалізації цієї підготовки.
Попри описані суперечності існують суттєві резерви та можливості для поліпшення ефективності підготовки майбутніх фрахівців транспортної галузі до профресійної комунікативної взаємодії.

Мета статті. Мета статті полягає у науковому обґрунтуванні концепції підготовки майбутніх фрахівців транспортної галузі до професійної комунікативної взаємодії. Актуальності набуває не лише теоретико-методологічне обґрунтування концепції підготовки майбутніх фрахівців транспортної галузі до профресійної комунікативної взаємодії, а й розроблення технології її практичного впровадження у ЗВО транспортного напряму України.

Виклад основного матеріалу. У контексті дослідження науковий інтерес становлять концепції профресійної підготовки, що відображають сучасні тенденції в модернізації вітчизняної професійної освіти. Під поняттям «концепція підготовки майбутніх фрахівців транспортної галузі до професійної комунікативної взаємодії» розумітимемо сукупність авторських ідей стосовно сутності педагогічного процесу, спрямованого на фрормування готовності майбутніх фрахівців транспортної галузі до профресійної комунікативної взаємодії, що ґрунтується на теоретико-методологічних положеннях, принципах і підходах.

Під час наукового пошуку розроблено концепцію підготовки майбутніх фрахівців транспортної галузі до професійної комунікативної взаємодії. Підґрунтям для розроблення концептуальних засад підготовки майбутніх фрахівців транспортної галузі до профресійної комунікативної взаємодії слугували такі концепти: методологічний - для з'ясування методологічних підходів і принципів авторської концепції; теоретичний - для з'ясування сутності ключових понять, змісту та структури підготовки майбутніх фрахівців транспортної галузі до професійної комунікативної взаємодії, для виокремлення критеріїв, показників і рівнів готовності, для обґрунтування педагогічних умов; практичний - для впровадження педагогічної системи підготовки майбутніх фрахівців транспортної галузі до профресійної комунікативної взаємодії.

Методологічний концепт слугує фрундаментом для побудови концепції, оскільки фрілософрія не лише породжує найбільш загальні уявлення про побудову світу, його пізнання, сенс життя, а й фрормує найбільш загальні принципи пізнання навколишнього світу, постає як методологія різних наук, зокрема педагогіки, психології, лінгвістики, методики навчання іноземних мов. Стрижнем методологічного концепту $€$ цілісна сукупність методологічних підходів (системного, компетентнісного, особистісно орієнтованого, диференційованого, культурологічного, комунікативного, діяльнісного, професійно орієнтованого, контекстного, аксіологічного) і принципів підготовки майбутніх фрахівців транспортної галузі до профресійної комунікативної 
взаємодії: загальнодидактичних (активності, наочності, свідомості, доступності та посильності, індивідуалізації навчання) і методичних (профресійної спрямованості, комунікативності, взаємодії основних видів мовленнєвої діяльності, інтерактивності, проблемності, автентичності навчальних матеріалів, міжпредметних зв'язків).

Упровадження сукупності зазначених підходів у процес підготовки майбутніх орахівців транспортної галузі до професійної комунікативної взаємодії аргументоване такими чинниками: системний підхід забезпечує функціонування всіх елементів цілісної системи профресійної підготовки в узгодженому порядку; компетентнісний підхід ґрунтується на об'єднанні профресійних теоретичних знань і практичних умінь у сорері транспортної діяльності як цілісного інтегративного, багаторівневого утворення, що $€$ результатом здобуття неперервної освіти фрахівців транспортної галузі; особистісно орієнтований підхід передбачає трансформацію змісту освіти через створення умов для цілісного розвитку особистісних якостей студентів, активізації їхніх внутрішніх резервів; диференційований підхід сприяє розподілу навчального матеріалу та уможливлює комфортність навчального процесу для кожного студента завдяки підвищенню якості освіти у цілому; культурологічний підхід оптимізує підготовку майбутніх фрахівців у крос-культурному контексті транспортної діяльності; комунікативний підхід скеровує навчальний процес на розвиток здатності студентів застосовувати теоретичні знання на практиці, усвідомлювати себе як реального учасника професійних комунікативних ситуацій, долати комунікативні бар'єри в професійній комунікативній взаємодії; діяльнісний підхід детермінує якісно нові підходи до фрормування практичних навичок спілкування, які впливають на характер професійної комунікативної взаємодії фрахівців транспортної галузі, та орієнтує заняття на опанування спілкування; профресійно орієнтований підхід скеровує профресійну підготовку на вирішення конкретних навчальних завдань у межах читання, перекладу, слухання та говоріння, що пов'язані 3 транспортом; контекстний підхід уможливлює відпрацювання теоретичних знань і практичних навичок у площині професійних контекстів, у яких за допомогою дидактичних засобів змодельовано дисциплінарний (предметний) та соціальний (профресійний) зміст професійної діяльності фрахівців транспорту; аксіологічний підхід сприяє організації мовної підготовки, у межах якої розвивається ціннісне ставлення до профресії, фрормуванню комплексу життєво важливих цінностей, усвідомленню культурно значущих характеристик навколишнього світу.

Дослідження орієнтовано на інтеграцію таких дидактичних і методичних принципів, як: принцип активності, що забезпечує активну участь, самостійність, зацікавленість студентів у навчанні професійної комунікативної взаємодії; принцип наочності, який сприяє поєднанню пояснювальних методів із демонстрацією практичних засобів провадження комунікативної діяльності (технічні пристрої, радіообладнання, мапи, схеми); принцип свідомості, що полягає у розумінні важливості комунікативної підготовки для професійної взаємодії в професійній діяльності; принцип доступності та посильності, який сприяє правильному розподілу навчального матеріалу для кращого засвоєння й опрацювання; принцип індивідуалізації навчання, що базований на врахуванні природних якостей і здібностей студентів, вихідному рівні знань для добору найбільш раціональних та адекватних методів навчання; принцип професійної спрямованості, який зумовлює ґрунтовне засвоєння комунікативних знань, розвиток необхідних комунікативних умінь і навичок, а також набуття майбутніми фрахівцями практичного досвіду комунікативної діяльності у галузі транспорту; принцип комунікативності, що спрямований на розвиток навичок мовлення і слухання, які є пріоритетними у професійній комунікації; принцип взаємодії основних видів мовленнєвої діяльності, що полягає в органічному поєднанні всіх елементів профресійної взаємодії: говоріння, слухання, письма та читання; принцип інтерактивності, який передбачає навчання в діалозі (відбір типових ситуацій профресійної взаємодії фрахівців транспортної галузі, створення на заняттях атмосфери, яка імітує реальне спілкування); принцип проблемності, що уможливлює розвиток навичок критичного мислення через проблемні ситуації, які потребують не лише знань 3 англійської мови, а й правильного рішення у професійній ситуації; принцип автентичності навчальних матеріалів, що пов'язаний із використанням реальних записів бортових носіїв, читанням й аналізом текстів оригінальних документів; принцип міжпредметних зв'язків, який обґрунтовує можливості отримання знань у площині їх міждисциплінарності, взаємодоповнюваності профресійних і гуманітарних дисциплін у контексті фрормування досвіду комунікативної взаємодії фрахівців транспортної галузі.

Теоретичний концепт передбачає обґрунтування й уточнення основних понять дослідження: «профресійна взаємодія», «комунікативні вміння», «профресійна комунікативна взаємодія майбутніх фрахівців транспортної галузі», усебічний аналіз яких дає змогу окреслити проблемне поле й аргументувати сутність дослідження, схарактеризувати структуру та зміст підготовки майбутніх фрахівців транспортної галузі до професійної комунікативної взаємодії, визначити критерії, показники й рівні її готовності, теоретично обґрунтувати педагогічні умови, упровадження яких в освітній процес ЗВО сприятиме результативному фрормуванню 
готовності майбутніх фрахівців транспортної галузі до професійної комунікативної взаємодії.

Концептуальне положення теоретичного концепту полягає у розумінні підготовки майбутніх фрахівців транспортної галузі до професійної комунікативної взаємодії як цілісної педагогічної системи, де: мета спрямована на фрормування готовності майбутнього фрахівця транспортної галузі до профресійної комунікативної взаємодії; основним завданням є опанування майбутніми фрахівцями профресійних комунікативних знань, набуття необхідних умінь і навичок для профресійної комунікативної взаємодії у транспортній галузі; зміст системи підготовки майбутніх фрахівців транспортної галузі відображає комплекс теоретичних і практичних положень, які забезпечують навчання професійної комунікативної взаємодії через насичення мовних дисциплін професійним контентом; підготовка майбутніх фрахівців транспортної галузі до профресійної комунікативної взаємодії організована з огляду на специфіку фахової підготовки у 3ВО, передбачає поєднання аудиторної й самостійної роботи, інтеграцію індивідуальних, міжособистісних, кооперативних форм навчання, а також координацію роботи викладачів фрахових, мовних і суспільно-гуманітарних дисциплін, кураторів, інструкторів тренажерного навчання, керівників науково-дослідних робіт тощо.

Практичний концепт провідної ідеї дослідження об'єднує основні положення методологічного й теоретичного концептів, відображає послідовність її впровадження в методичному плані, що доцільно трактувати як технологію підготовки майбутніх фрахівців транспортної галузі до профресійної комунікативної взаємодії (далі - технологія). Технологія передбачає поетапне впровадження педагогічних умов, оновленого змісту мовних дисциплін, інноваційних форм і методів навчання, діагностику аналізованої властивості, моніторинг ефективності навчального процесу на різних етапах підготовки.

Висновки. Отже, запропонована концепція підготовки майбутніх фрахівців транспортної галузі до профресійної комунікативної взаємодії у ЗВО транспортного спрямування складається 3 трьох концептів: методологічного, теоретичного й практичного, які перебувають у взаємозв'язку та створюють підґрунтя для її практичного впровадження в освітній процес майбутніх фрахівців транспортної галузі.

\section{БІБЛОГРАФІЧНИЙ СПИСОК:}

1. Міністерство інфрраструктури України : офріційний сайт. URL: https://mtu.gov.ua/.

2. Великий тлумачний словник сучасної української мови (з дод. і допов.) / упоряд. і гол. ред. В.Т. Бусел. Ірпінь : Перун, 2005. 1728 с.

3. Коджаспирова Г.М., Коджаспиров А.Ю. Словарь по педагогике. Москва ; Ростов-на-Дону : МapT, 2005. 448 c.

4. Яковлев Е.В., Яковлева Н.О. Педагогическая концепция: методологические аспекты построения. Москва : ВЛАДОС, 2006. 239 с.

5. Волкова Н.П. Педагогіка : навчальний посібник ; 2-е вид., доп. і перероб. Київ : Академвидав, 2007. 616 c. 